\title{
The 1930s Depression in Latin America: A Macro Analysis
}

\author{
Michael. J. TwomeY* \\ University of Michigan, Dearborn
}

The Depression of the 1930s continues to command attention; some urge wholesale revocation of the policy responses it engendered, while many predict its imminent return. An important trend in recent academic studies of the Depression is the broadening of the geographical range of countries analyzed, while adopting a more consciously comparative perspective. 'This paper ${ }^{2}$ extends that work by analyzing selected experiences in Latin America, providing and commenting on comparisons with both Europe and North America. Its goal is to deepen our analytical understanding of the factors determining changes in prices and output during the period. The basic framework of discussion is simple aggregate supply and demand curves, various aspects of which are investigated below in the different parts of the paper, leading finally to some broad conclusions.

The interwar evolution of real output for six Latin American countries is presented in Graph 1; the post-1929 decline in output was greatest in Chile, least in Colombia, while Honduras did not experience a typical cycle during the early 1930s. ${ }^{3}$ The decline in GDP started before 1928

*Address correspondence to Dr. Michael J. Twomey, Department of Economics, University of Michigan, Dearborn, Mich. 48128.

${ }^{1}$ Examples are Van der Wee (1972), Kindleberger (1973), Brunner (1980), and Latham (1981).

${ }^{2}$ An earlier version (Twomey 1982a) was presented to a symposium on "The Effects of the 1929 Depression in Latin America" at the International Congress of Americanists in Manchester, England. The author is indebted to the other participants, as well as Albert Berry and David Feeny, for their helpful comments. Many of the individual country studies from that symposium will appear in a book to be edited by Rosemary Thorp. To a considerable degree, the present paper is a response to Carlos Diaz Alejandro's many insights about the period as presented, for example, in his 1981 working paper.

${ }^{3}$ Some comments are needed on the reliability of this data. Aggregate GDP estimates were not made anywhere during the early 1930s, and the present-day quality of those estimates for the Latin American countries probably varies considerably. The Argentine and Colombian data resulted from CEPAL efforts in the early 1950s, and would arguably reflect the better statistics of those two countries, while not benefiting from the general learning experience of national income accounting that should be reflected, for example, in the chronologically later Mexican estimates. The Honduran data are something of an 


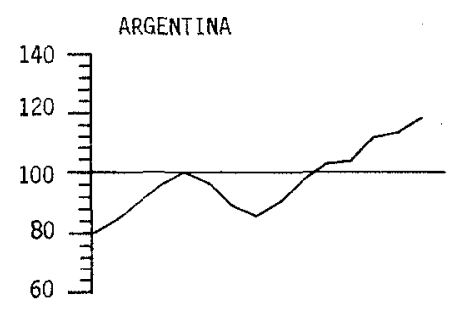

BRAZIL

CHILE
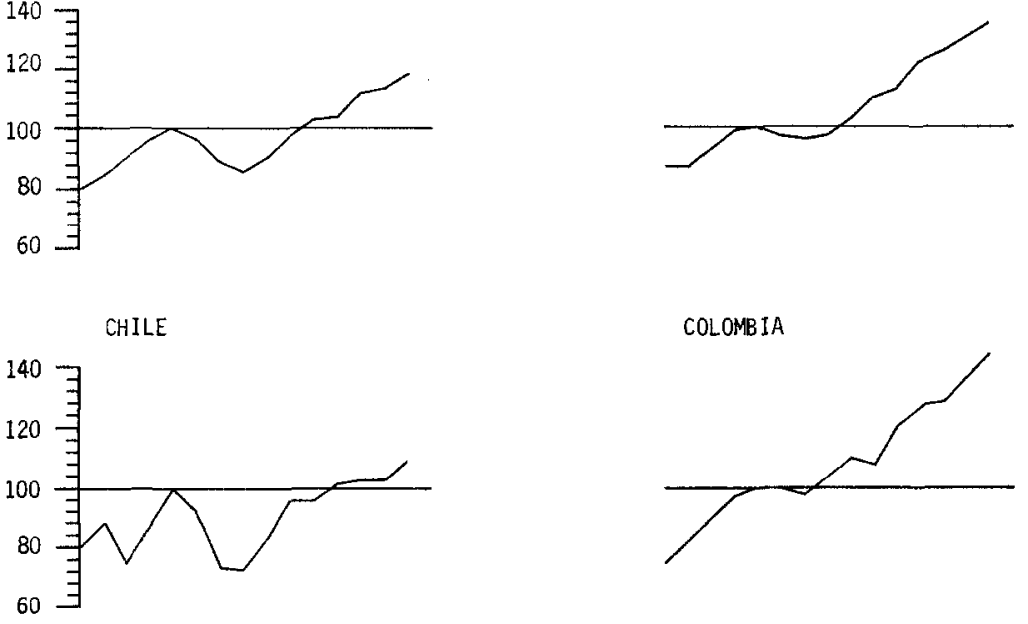

COLOMB IA

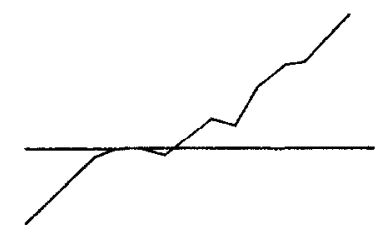

HONDURAS

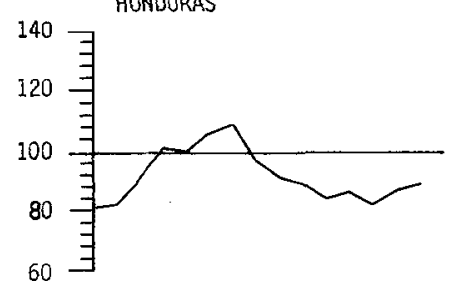

MEXICO
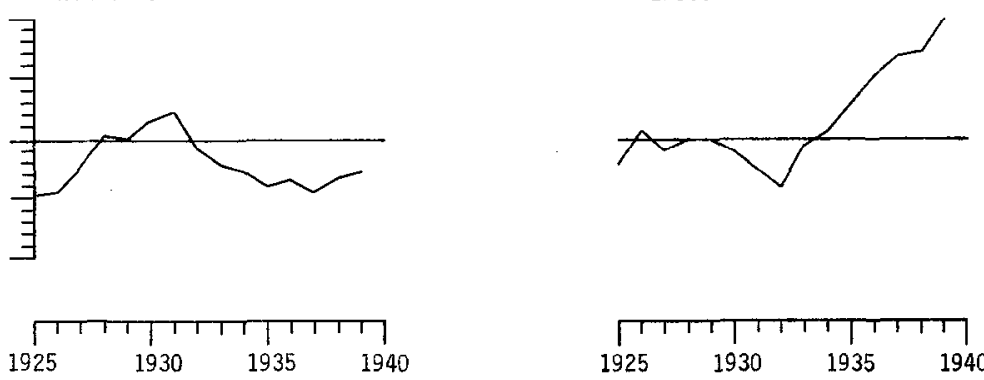

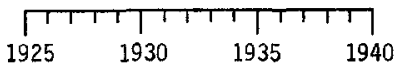

GRAPH 1. Index numbers of real GDP, $1929=100$.

in Mexico (as it did in Australia and elsewhere). ${ }^{4}$ Various countries had significant overall growth during the period. Some basic statistics on macroeconomic variables are presented in Table 1 , for a large number of countries. One aspect that stands out is the significantly poorer performance of the U.S., Canada, Austria, and Germany compared to either industrial or nonindustrial countries. In particular, the Latin American

anomaly; coming from the Central Bank they have a certain authority, but it is not clear how extensive was the original data base. The Chilean estimates do not cover services, and in this sense they are the weakest presented. It is generally recognized that the Colombian price data do not fully represent nonagricultural items, which suggests an upward bias of the real values of government and other activities during the early 1930s, and thus an underestimate of the decline in output.

${ }^{4}$ An examination of sectorally disaggregated GDP totals would show that fluctuations were spread throughout the economies of each country, so that, for example, industry and agriculture closely paralleled total output. This observation does not deny that export demand had started to decline before 1929, nor will this paper enter into the question of the more fundamental causes worldwide of the Depression. 
TABLE 1

Descriptive Statistics

\begin{tabular}{|c|c|c|c|c|c|c|c|c|c|c|}
\hline \multirow[b]{2}{*}{ Country } & \multicolumn{2}{|c|}{ Year } & \multicolumn{6}{|c|}{$\begin{array}{l}\text { Peak to Trough } \\
\text { (Percentage Decline in) }\end{array}$} & \multicolumn{2}{|c|}{$\begin{array}{c}\text { 1937-1939 } \\
\text { Index } \\
(\text { Peak }=100)\end{array}$} \\
\hline & Peak & Trough & $Q$ & 10 & $P$ & $Y$ & $M$ & $V$ & $Q$ & $I-O$ \\
\hline Argentina & 1929 & 1932 & 14 & 18 & 22 & 33 & 22 & 19 & 114 & 129 \\
\hline Brazil & 1929 & 1931 & 4 & 3 & 12 & 16 & 1 & 15 & 131 & 152 \\
\hline Chile & 1929 & 1932 & 27 & 15 & +4 & 24 & +34 & 44 & 104 & 123 \\
\hline Colombia & 1929 & 1931 & 2 & 7 & 36 & 38 & 31 & 10 & 136 & 202 \\
\hline Honduras & * & 1934 & 11 & 13 & 8 & 19 & NA & NA & 86 & 112 \\
\hline Mexico & $1929^{a}$ & 1932 & 16 & $9^{b}$ & 21 & 34 & 3 & 32 & 132 & 153 \\
\hline Canada & 1929 & 1933 & 30 & 33 & 22 & 42 & 28 & 20 & 100 & 106 \\
\hline U.S. & 1929 & 1933 & 29 & 25 & 24 & 46 & 26 & 27 & 103 & 116 \\
\hline Australia & 1929 & 1931 & 9 & 24 & 17 & 28 & 20 & 10 & 117@ & $116 @$ \\
\hline India & 1929 & 1931 & 2 & 5 & 26 & 28 & NA & NA & 104 & 152 \\
\hline Japan & * & 1931 & + & + & 19 & 18 & 12 & 6 & 150 & 193 \\
\hline Turkey & $*$ & 1932 & + & + & 15 & 12 & $4^{c}$ & 9 & 164 & 252 \\
\hline Austria & 1929 & 1933 & 22 & 27 & 17. & 25 & 36 & +17 & 86 & 106 \\
\hline Bulgaria & 1928 & 1933 & 9 & 33 & 30 & 35 & 10 & 28 & 150 & $\mathrm{NA}$ \\
\hline Czech'ia & 1929 & 1934 & 17 & 34 & 10 & 26 & 3 & 23 & 98@ & $96 @$ \\
\hline Denmark & * & 1932 & + & 9 & 10 & 11 & 6 & 5 & 121 & 138 \\
\hline Finland & 1928 & 1931 & 9 & 22 & 16 & 23 & 3 & 21 & 136 & 146 \\
\hline France & 1929 & 1934 & 13 & 25 & 18 & 29 & +6 & 34 & 86 & 78@ \\
\hline Germany & 1928 & 1932 & 23 & 39 & 29 & 40 & 37 & 4 & 139 & 135 \\
\hline Greece & 1930 & 1931 & 8 & + & 11 & 9 & 12 & +3 & 122 & 159 \\
\hline Holland & 1930 & 1934 & 12 & 10 & 12 & 24 & 19 & 4 & 100 & 105 \\
\hline Hungary & 1930 & 1933 & 9 & 7 & 21 & 28 & 28 & 0 & 112 & 136@ \\
\hline Italy & 1929 & 1931 & 8 & 14 & 22 & 23 & 13 & 11 & 113 & 114 \\
\hline Norway & 1929 & 1931 & 14 & 22 & 8 & 12 & 11 & 1 & 115 & 133 \\
\hline Spain & 1929 & 1933 & 8 & 16 & 5 & 13 & +9 & 20 & NA & NA \\
\hline Sweden & 1930 & 1932 & 12 & 13 & 10 & 16 & +1 & 17 & 123 & 149@ \\
\hline $\mathrm{U} . \mathrm{K}$. & 1929 & 1932 & 6 & 11 & 12 & 11 & 0.5 & 10 & 118 & 128 \\
\hline Yugoslavia & 1929 & 1932 & 12 & $\mathrm{NA}$ & 23 & 32 & 24 & 11 & 112 & NA \\
\hline
\end{tabular}

Notes. $\mathrm{Q}=$ Real Output; $\mathrm{IO}=$ Industrial Output; $\mathrm{P}=$ Price Level; $\mathrm{Y}=$ Nominal Income (or expenditure); $\mathrm{M}=$ Money Supply; $\mathrm{V}=$ Velocity. $\mathrm{NA}=$ not available.

An asterisk indicates that the country did not experience a "normal" cycle; for those countries' calculations, 1929 is taken as the base year, and the year of lowest nominal GNP as the trough year. A "+" indicates that that item rose, rather than fell, during the period. A "@" indicates average is for less than three years.

Sources are discussed in the Appendix.

${ }^{a}$ Solis (1970) reports real GDP about 0.1\% higher in 1928 than 1929. As industrial production peaked in the latter year, and for ease of presentation, 1929 is used as the peak year in this and subsequent tables.

${ }^{b}$ This total, for manufacturing output, is from NAFINSA (1978, p. 156). The corresponding drop in all manufacturing (including processing of minerals and petroleum), is $31 \%$ (Solis 1970, p. 91).

c Demand deposits only. 
countries perform on average about as well as the European countries, with respect to either total output or industrial production. ${ }^{5}$ As has been suggested for the U.S.-European comparison by Gordon and Wilcox (1980), the different output experiences reflect both supply and demand factors. We turn first to the relatively less studied supply issues.

\section{THE SUPPLY CURVE}

For over a decade, contemporary macroeconomics has been refocusing attention on the behavior of aggregate supply. ${ }^{6}$ In their review of Temin (1976), Gandolfi and Lothian (1977) suggest that more attention should be given to this aspect of the Depression; it is hoped that a comparative analysis will be especially useful.

Supply curves were econometrically estimated using the formulation $P=f\left(Q, P^{\mathrm{e}} / P, T\right)$, where $P$ is the price level, ${ }^{7} Q$ is real output, $P^{\mathrm{e}}$ is the expected level of prices, and $T$ is the time variable. ${ }^{8}$ The time period covered is basically 1920-1939. The results of 2SLS estimates (using the Keynesian version of autonomous demand presented below) are presented in Table 2. Most of the coefficients have the expected signs, and the coefficients of determination are generally quite acceptable. The slopes

${ }^{5}$ The varied nature of the Latin American industrialization process is discussed by the contributors to the Thorp volume. Here, we might only note that, while Chu (1972 p. 52), in commenting on industrial development in Argentina and Colombia, is tempted to "interpret these changes as a shift from capital goods and intermediate products during the 1920's to consumer goods during the 1930's" (with textiles being a prime example), Fishlow (1972, pp. 332-335) sees essentially the opposite kind of movement in Brazil.

${ }^{6}$ Indeed, the rational expectations school attempts to discredit most standard Keynesian policy conclusion by its "supply side" insights. The reader will note that our supply analysis is in fact compatible with the rational expectations school, if the dramatic changes in exports, exchange rates, government expenditures, etc. are interpreted as having been unexpected, which seems a reasonable approximation. However, our analysis of aggregate demand ends up being almost textbook Keynesian. Some argue that the monetarist/Keynesian labels are obsolete; we should recognize, nevertheless, the broad analytical gaps dividing, for example, the contributors to the Brunner (1980) volume.

${ }^{7}$ The standard CEPAL (ECLA) analysis of the Depression involves changes in relative prices refocusing sources of growth from external to internal factors. International trade models traditionally handle relative prices assuming full employment, and, of course, a change in relative prices should not change the price level. This paper seeks to complement the CEPAL analysis by focusing on absolute prices and variations in output, enabling the Latin American experience to be placed in a broader perspective.

${ }^{8}$ The estimate for output, to be referred to as the slope of the supply curve, is the coefficient of most interest to us here, and should be positive. The estimated coefficient on time is expected to be negative, as capital accumulation and technological progress allow the same quantity of goods to be produced at a lower price. Following current analysis among macroeconomists, an increase in expected prices will shift the supply curve up, implying that that variable's estimated coefficient should have a positive sign. $P^{\mathrm{e}}$ is calculated by assuming that the previous year's rate of inflation is expected to remain constant, i.e., $P_{t}^{c}=P_{-1}\left(1+d P_{-1} / P_{-2}\right)$. More sophisticated modeling of expectations formulations did not yield significantly different estimates, especially with respect to output. 
TABLE 2

Supply Equations

\begin{tabular}{|c|c|c|c|c|c|c|}
\hline Country & Constant & $P^{\mathrm{e}} / P$ & Output & Time & $R^{2}$ & $\begin{array}{c}\text { Number } \\
\text { Obs. }\end{array}$ \\
\hline \multirow[t]{2}{*}{ Argentina } & 7.11 & 0.25 & 1.22 & -0.04 & 0.66 & 15 \\
\hline & 2.95 & 0.22 & 0.30 & 0.01 & & \\
\hline \multirow[t]{2}{*}{ Brazil } & -31.4 & 0.77 & 3.72 & -0.08 & 0.71 & 19 \\
\hline & 11.1 & 0.62 & 1.17 & 0.03 & & \\
\hline \multirow[t]{2}{*}{ Chile* } & -0.73 & -0.51 & 1.02 & 0.04 & 0.88 & 12 \\
\hline & 3.15 & 0.65 & 0.76 & 0.02 & & \\
\hline \multirow[t]{2}{*}{ Colombia } & -40.8 & 0.18 & 4.95 & -0.20 & 0.28 & 15 \\
\hline & 19.6 & 0.46 & 2.13 & 0.09 & & \\
\hline \multirow{2}{*}{ Honduras } & 2.47 & -0.02 & 0.31 & 0.008 & 0.30 & 9 \\
\hline & 1.39 & 0.20 & 0.21 & 0.006 & & \\
\hline \multirow[t]{2}{*}{ Mexico } & -8.87 & 0.54 & 1.45 & -0.03 & 0.44 & 17 \\
\hline & 3.98 & 0.33 & 0.43 & 0.01 & & \\
\hline \multirow[t]{2}{*}{ United States } & 2.10 & 0.23 & 0.58 & -0.026 & 0.92 & 20 \\
\hline & 0.42 & 0.13 & 0.10 & 0.002 & & \\
\hline \multirow[t]{2}{*}{ Canada } & 1.11 & 0.29 & 0.43 & -0.02 & 0.95 & 18 \\
\hline & 0.48 & 0.17 & 0.05 & 0.001 & & \\
\hline \multirow[t]{2}{*}{ Australia } & -1.56 & 0.39 & 1.77 & -0.005 & 0.77 & 18 \\
\hline & 0.60 & 0.31 & 0.34 & 0.001 & & \\
\hline \multirow[t]{2}{*}{ Japan } & -1.69 & -0.06 & 2.44 & -0.09 & 0.62 & 20 \\
\hline & 4.70 & 0.35 & 0.53 & 0.02 & & \\
\hline \multirow[t]{2}{*}{ Austria } & 4.18 & 0.04 & 0.29 & -0.02 & 0.78 & 14 \\
\hline & 0.52 & 0.17 & 0.20 & 0.004 & & \\
\hline \multirow[t]{2}{*}{ Bulgaria } & 3.93 & 0.92 & 0.40 & -0.057 & 0.88 & 16 \\
\hline & 0.71 & 0.34 & 0.21 & 0.008 & & \\
\hline \multirow[t]{2}{*}{ Czechoslovakia } & 3.31 & -0.05 & 0.33 & -0.006 & 0.75 & 13 \\
\hline & 0.47 & 0.25 & 0.11 & 0.001 & & \\
\hline \multirow[t]{2}{*}{ Denmark } & 4.42 & 0.40 & 0.05 & -0.01 & 0.43 & 19 \\
\hline & 7.67 & 0.37 & 0.93 & 0.02 & & \\
\hline \multirow[t]{2}{*}{ Finland } & 2.00 & 1.29 & 0.58 & -0.03 & 0.56 & 14 \\
\hline & 1.27 & 0.60 & 0.26 & 0.01 & & \\
\hline \multirow[t]{2}{*}{ France } & -6.59 & 0.48 & 1.30 & 0.01 & 0.76 & 20 \\
\hline & 20.58 & 0.23 & 0.32 & 0.007 & & \\
\hline \multirow[t]{2}{*}{ Germany } & -2.51 & 0.70 & 0.72 & -0.04 & 0.96 & 7 \\
\hline & 3.08 & 0.42 & 0.26 & 0.01 & & \\
\hline \multirow[t]{2}{*}{ Greece } & 2.01 & 0.13 & 0.51 & 0.026 & 0.83 & 10 \\
\hline & 2.37 & 0.19 & 0.74 & 0.25 & & \\
\hline \multirow[t]{2}{*}{ Holland } & 3.38 & 0.36 & 0.16 & -0.02 & 0.97 & 13 \\
\hline & 1.06 & 0.08 & 0.11 & 0.002 & & \\
\hline \multirow[t]{2}{*}{ Hungary } & -9.26 & -0.11 & 1.77 & -0.06 & 0.78 & 13 \\
\hline & 5.47 & 0.55 & 0.67 & 0.01 & & \\
\hline \multirow[t]{2}{*}{ Italy } & -7.93 & 0.38 & 2.81 & -0.06 & 0.61 & 18 \\
\hline & 3.64 & 0.50 & 0.79 & 0.01 & & \\
\hline \multirow{2}{*}{ Norway } & -19.7 & 1.13 & 3.42 & -0.11 & 0.54 & 20 \\
\hline & 10.5 & 0.60 & 1.45 & 0.03 & & \\
\hline Spain & 7.55 & 0.39 & -0.28 & -0.004 & 0.41 & 14 \\
\hline & 7.58 & 0.24 & 0.77 & 0.01 & & \\
\hline
\end{tabular}


TABLE 2-Continued

\begin{tabular}{lrrrrrc}
\hline Country & Constant & $P^{\mathrm{e}} / P$ & Output & Time & $R^{2}$ & $\begin{array}{c}\text { Number } \\
\text { Obs. }\end{array}$ \\
\hline Sweden & -5.13 & $-\mathbf{0 . 4 2}$ & 1.25 & -0.05 & 0.61 & 17 \\
United Kingdom & 3.77 & 0.40 & 0.46 & 0.01 & & \\
& -9.86 & 0.54 & 1.83 & -0.05 & 0.74 & 20 \\
Yugoslavia & 4.66 & 0.26 & 0.57 & 0.01 & & \\
& -4.58 & 0.57 & 1.53 & -0.06 & 0.86 & 10 \\
& 2.88 & 0.57 & 0.47 & 0.02 & &
\end{tabular}

Notes. All variables-except time-converted to logarithms. Standard errors listed below estimated coefficients. Data sources are discussed in the appendix; the price index is usually CPI and the output is usually GDP. Equations are estimated 2SLS, for which the excluded exogenous variables (i.e., the determinants of the demand curve) are nominal government expenditures, exports, and, where available, investments.

* Values of $P^{\mathrm{c}}$ and $P$ were assumed to be equal for Chile in 1928 and 1929.

of the supply curves in the U.S. and Canada are in the lowest third of the 26 countries considered. In particular, the curves for the Latin American countries have relatively high slopes. ${ }^{9}$

Part of the explanation for the marked differences in supply responses would be that primary production is more price inelastic than industrial activities, as farmers have few alternative income sources, while industrialists may cut back on output in the short run. In fact, the estimated output coefficients of our supply curves are negatively correlated both to 1929 per capita income levels and percentage of income generated by industry. ${ }^{10}$ Another factor often considered a crucial determinant of the responsiveness of aggregate supply is wage flexibility, especially during the period in question. Our attempts at expanding the above supply specification for the European countries to include wage factors were not successful, and will not be reported here. ${ }^{11}$ The limited data available suggest a marked decline in (urban and mining) real wages in Chile, and

${ }^{9}$ Note that a steep slope implies a low elasticity of supply with respect to prices. This recalls what the structuralists were saying two or three decades ago. The monetarist position is also reflected by specifying supply as a function of expected prices; even "surprise" policy innovations will not have any long term effects on output.

${ }^{10}$ Per capita income calculated from the sources listed in the Appendix, supplemented by Zimmerman (1962). For the Latin American countries, the per capita income levels were similar to those of a number of southern and eastern European countries, although the former were generally less industrialized than the latter. Note also that agricultural output in the U.S. did not fall as much as that of industry until the mid-thirties climatic problems hit.

${ }^{11}$ Because time series on wages are scarcer, we do lose some countries, and shorten the time spans in others. Two plausible hypotheses were tested: a "kinked" supply curve, and one in which real or nominal wages also enter on the right hand side. 
near stability in Argentina (and perhaps Peru, although not Colombia), in contrast to the non-Latin American countries in Table 1, where real wages (in manufacturing) increased.

In summary, inelastic supply curves in Latin America, which have frustrated expansionary demand policies in the post-World War II era, tended to cushion output declines during the Depression. The steepness of the supply curves reflects the more traditional structure of production: what is not clear is the degree to which declining real wages and/or other income redistribution factors may have accounted for this. These research issues continue to command contemporary as well as historical interest.

\section{THE DEMAND RELATIONS}

Two standard treatments of aggregate demand can be distinguished, one focusing on the quantity of money, ${ }^{12}$ the other emphasizing autonomous levels of expenditure. The monetarist theory explaining changes in nominal income $(Y)$ by changes in the nominal money supply $(M)$ needs no introduction here. The alternative model will specify nominal demand as a function of the nominal values of investment $(n$, government expenditures $(G)$, and exports $(X)$. While equally acceptable from a theoretical point of view, ${ }^{13}$ this is not the traditional version. Many textbooks discuss changes in demand in real terms, effectively assuming constant prices, but such was not the case in the early 1930s, in either industrial or nonindustrial countries, when both absolute and relative prices changed considerably. ${ }^{14}$

${ }_{12}$ As a critique of Friedman and Schwartz's classic Monetary History of the United States, Temin's Did Monetary Forces Cause the Great Depression seems mistakenlyor provocatively-mistitled, because the former work does not present such a unicausal analysis. When originally writing a History of the Economic Analysis of the Great Depression in America, Stoneman considered (in 1969), "the Friedman-Schwartz interpretation a very minor contribution to the lengthy literature on the Depression," and relegated it to a small footnote. (1979, vi). The views of that author, as those of many others, have changed since then.

${ }^{13}$ Exports generate demand not solely because of the quantity of goods sold, but, rather, due to what producers can buy with their income, which is determined by that quantity and some price whose determination is also important. Of course, it is easy to defend a model wherein government policy makers determine their nominal expenditures based, for example, on estimated nominal budget revenues. That may not be true of an individual industrialist making an investment decision, but an argument can be made that total national investment is determined in nominal terms by, say, the nominal quantity of money or credit. This model has a direct parallel in the monetarist story of the nominal quantity of money determining nominal income. Note, however, that one study asking some questions similar to ours, that of Pryor (1979), analyzed taxes, etc. in real terms.

${ }^{14}$ Recent theoretical work on nontraded goods has emphasized that price and income effects in that sector often counteract those in the traded-goods sector, and that complete inclusion of price and output effects usually removes all effects of a devaluation except price increases, (in contrast to that lengthy part of international trade literature on the effects of devaluations which also concentrated on changes in output, exports, and imports, 
TABLE 3

Coefficients of Correlation of $d Y$ on $d M$ and $d G, d I$, and $d X$

\begin{tabular}{|c|c|c|c|c|c|c|c|}
\hline Country & $\begin{array}{c}R^{2} \\
\text { using } \\
d M\end{array}$ & $\begin{array}{c}R^{2} \\
\text { using } \\
d G, d I \\
\text { and } d X\end{array}$ & $\begin{array}{c}R^{2} \\
\text { using } \\
\text { only } \\
d G, d X\end{array}$ & Country & $\begin{array}{c}R^{2} \\
\text { using } \\
d M\end{array}$ & $\begin{array}{c}R^{2} \\
\text { using } \\
d G, d I \\
\text { and } d X\end{array}$ & $\begin{array}{c}R^{2} \\
\text { using } \\
\text { only } \\
d G, d X\end{array}$ \\
\hline U.S. & 0.84 & 0.89 & & Austria & 0.00 & & 0.81 \\
\hline \multirow[t]{2}{*}{ Canada } & 0.59 & 0.89 & & Bulgaria & 0.72 & & 0.77 \\
\hline & & & & Czech'ia & 0.20 & & 0.72 \\
\hline Australia & 0.20 & 0.84 & & Denmark & 0.13 & 0.88 & \\
\hline \multirow[t]{2}{*}{ Japan } & 0.83 & 0.93 & & Finland & 0.45 & & 0.90 \\
\hline & & & & France & 0.04 & & 0.76 \\
\hline Argentina & 0.39 & 0.84 & & Germany & 0.55 & & 0.99 \\
\hline Brazil & 0.17 & & 0.69 & Greece & 0.00 & & 0.54 \\
\hline Chile & 0.18 & & 0.66 & Hungary & 0.38 & 0.78 & \\
\hline Colombia & 0.61 & 0.78 & & Italy & 0.26 & 0.83 & \\
\hline Honduras & NA & 0.93 & & Holland & 0.30 & 0.75 & \\
\hline \multirow[t]{5}{*}{ Mexico } & 0.07 & 0.78 & & Norway & 0.13 & 0.97 & \\
\hline & & & & Spain & 0.03 & 0.08 & \\
\hline & & & & Sweden & 0.40 & 0.88 & \\
\hline & & & & U.K. & 0.13 & 0.97 & \\
\hline & & & & Yugoslavia & 0.45 & 0.64 & \\
\hline
\end{tabular}

Notes. All variables in nominal values. $\mathrm{NA}=$ not available:

Let us first compare the two demand models with simple regressions reflecting a pure monetary explanation and a straightforward "Keynesian" autonomous expenditure framework. The coefficients of correlation for two equations, one using $d M$, and the other $d X, d I$, and $d G$, to explain $d Y$, reveal in Table 3 the latter to be uniformly superior to the former. ${ }^{15}$ Although this result might be interpreted as evidence against the monetarists and in favor of the aggregate expenditures school, it is perhaps more useful to consider it merely as a justification for our procedure of analyzing the proximate causes of the decline in output in terms of the Keynesian variables. ${ }^{16}$

still assuming, at least implicitly, a flat supply curve). Thus, the inflationary fear of devaluations on the part of policy makers in the 1930s finds theoretical support today in analyses of the long run, although there may be beneficial output effects for a short term.

${ }^{15}$ This conclusion is robust for specifications in either levels or first differences, and is still true if the multipliers are constrained to equality. " $d$ " is the first difference operator.

${ }^{16}$ We will discuss below how abandonment of the gold standard severed the relation between income and the money supply. Another reason for this paper's concentration on autonomous expenditures is the diffeulty in modeling the transmission mechanism of monetary factors; interest rate data are difficult to find, and, moreover, it is not clear that the Keynesian separation of savings and investment decisions, which underlies the IS-LM 
For many years, the standard Keynesian interpretation of the U.S. experience was that demand dropped because of a decline in investment, counteracted eventually by an increase in government expenditures. While not wishing even to attempt a summary of recent research for that country, ${ }^{17}$ it should be noted that for most of the other industrial countries the macro variable which fell the most was not investment but exports. ${ }^{18}$ Apparently, the more general experience was that external factors were the most important cause of the decline of aggregate demand during the Depression in the industrial countries.

Data on investments in Latin America are poor, and this type of comparison is more difficult to make in the region. The estimates presented in Table 4 do not permit a general characterization; the decline of exports was larger than that of investments in Mexico and Honduras, and perhaps also Colombia, although probably not in Argentina. This observation must be qualified by considering the import content of investments. The CEPAL studies on Colombia and Argentina provide data suggesting marginal propensities to import from total investments of 0.46 in Colombia, and 0.28 in Argentina. Other sources indicate about 0.20 for Australia and Canada. ${ }^{19}$ This can be disaggregated; imports of machine-made goods had a marginal import content of 0.78 in Colombia, 0.68 in Argentina, and 0.39 in Canada; investment in construction goods rather uniformly had an import coefficient of 0.10 . This is important, because construction typically accounted for over half of investment outlays. ${ }^{20}$ Adjusting the investment figures for their import content, it would seem that the decline of investment was probably somewhat less important than that of exports in the four Latin American countries for which we have data, and which, it should be noted, happen to reflect a broad variety of price and output experiences.

For most of the countries considered worldwide, the government acted as an absorber of the demand shock. In fact, in about $40 \%$ of the countries, nominal government expenditures were greater in the trough year than they were in the peak year. The degree to which this countercyclical expenditure pattern was the direct result of conscious policy is still debated. ${ }^{21}$ However, Table 4 also indicates that the magnitude of the fall

framework, is valid for these third world countries, especially during the period under consideration. See Fitzgerald (1982) for further comments.

${ }^{17}$ See Temin (1976), Brunner (1980), Trescott (1982), and Zevin (1982).

18 Data presented for the countries in Table 1 in Twomey (1982a). In addition to the U.S., exceptions to this generalization are Canada, Germany, and Australia.

${ }^{19}$ See Twomey (1982b) for details.

${ }^{20}$ Data are presented in Twomey (1982a).

21 The classic statement on Brazil was Furtado (1963), the challenge to it is conveniently summarized in Pelaez (1979), and its essential validity is reaffirmed by, anong others, Fishlow (1972). 
TABLE 4

Exogenous Variables in Latin America during the Depression ( $Q$ is Real Output Index (Peak Year's Value $=100$ ); Other Data in Nominal Values, in Millions of National Currency Units)

\begin{tabular}{lcrrrrrr}
\hline Country & Year & $Q$ & GDP & Investment & Export & Gov't \\
\hline Argentina & 1929 & 100 & 9818 & 1601 & 2167 & 988 \\
& 1932 & 86 & 6579 & 434 & 1288 & 850 \\
& 1938 & 113 & 10,176 & 1024 & 1400 & 1278 \\
Colombia & 1929 & 100 & 944 & 177 & 122 & 150 \\
& 1931 & 97 & 590 & 57 & 80 & 114 \\
& 1938 & 136 & 1256 & 160 & 144 & 163 \\
Honduras & 1929 & 100 & 185 & 15 & 75 & 15 \\
& 1932 & 98 & 155 & 6 & 57 & 12 \\
& 1938 & 88 & 162 & 12 & 40 & 12 \\
Mexico & 1929 & 100 & 4244 & 150 & 590 & 276 \\
& 1932 & 84 & 2821 & 67 & 256 & 212 \\
& 1938 & 130 & 6818 & 302 & 710 & 504 \\
\hline
\end{tabular}

Sources. Argentina. CEPAL (1958b). GDP and investment were calculated using the output and price indexes of CEPAL together with official estimates of nominal GDP and investment in 1935, as reported in Diaz Alejandro (1970, pp. 398). This procedure avoids (most of) the large change in relative prices discussed in op cit., p. 29.

Colombia. CEPAL (1957). GDP deflator in Cuadro 32 used to calculate nominal values of GDP. As indicated in Table 1, the reported decline in Colombian prices is greater than that of any other country. This series appears to give too high a weight to food products, and thus probably exaggerates the drop in nominal GDP and investments between 1929 and 1931. Nominal value of exports from League of Nations Statistical Year Book. Government totals include state and local governments.

Honduras. All data from Tosco (1957).

Mexico. Quantity index and nominal GDP from Solis (1970). Exports and government totals from Solis and Anuario Estadistico. Investment estimated from the data in Fitzgerald (1981, Table 5).

in investment and exports was much too large to be absorbed by increased government expenditures, at least in Latin America. ${ }^{22}$

A comparison of the relative sizes of the movements in autonomous variable ${ }^{23}$ is presented in Table 5. Supporting conventional interpretations of the period, Brazil generated the largest increments in fiscal deficits. Although Brazil and other countries eventually lowered them later in the

${ }^{22}$ Although the data are too cumbersome to be included here, it might be noted that the estimates provided in Twomey (1982a) suggest that the decline in foreign loans and direct investment was rather small compared to the overall reduction in domestic investment, a conclusion somewhat at odds with Fleisig (1975).

${ }^{23}$ We will look at differences with respect to 1929 , for the statistical motive of avoiding differences in reporting procedures of government spending and receipts, especially with regard to utilities. 
decade, Mexico raised hers. ${ }^{24}$ Budget deficits were allowed to increase in 1930 in most countries; subsequently, tax schedules were altered ${ }^{25}$ in an attempt to compensate for declining tariff revenue. Contrary to what would be expansionary fiscal policy, taxes rose in two of our six countries, rather appreciably in Argentina.

Many discussions of the Depression era describe dramatic measures taken by the various governments to reduce imports, in order to remedy the serious balance of payments problems. In fact, large improvements over the 1929 trade account surpluses had been achieved by Colombia in 1930 , Brazil in 1931, Argentina and even Chile in 1932. See Graph 2. The change in the import function was certainly significant in all cases, and can be attributed to devaluations, tariffs, and lower external prices. The empirical separation of these effects would be quite difficult. ${ }^{26}$ The changes in the trade surpluses were apparently larger in relative terms than the increases in the fiscal deficits. ${ }^{27}$ Ecuador and Peru also engaged in budget balancing between 1929 and 1932, although its negative effect in Ecuador was counterbalanced by an increase in her trade surplus.

Two related points may be mentioned. Firstly, the data on exports should ideally be modified to account for remission of profits. These amounted to $19 \%$ of export receipts in Colombia, $21 \%$ in Argentina, $48 \%$ in Honduras, perhaps $43 \%$ in Mexico (in 1926), while the "nonreturned value" of Chilean copper exports (40\% of total 1929 exports) amounted

${ }^{24}$ Pelaez notes that between May 1931 and February 1933, 500 million milreis, or approximately one third of the receipts of the National Coffee Council, were credits from the Banco do Brasil and the National Treasury. This would have been about $2 \%$ of annual national output. In contrast, the 1932 deficit of the State of Sao Paulo was about 100 million milreis above what it had been in 1928 . While recognizing the dominating inffuence of the evolving political situation of the Mexican revolution, Cardenas (1982) argues that the late 1930s deficit spending was the result of conscious countercyclical policy. Chile's response to the disintegration of its export market was continued large deficit spending; in the absence of external finance, this created considerable inflationary pressures. One result is that our estimate of the real deficit declines, as prices (either wholesale or CPI) surpassed their 1929 level in 1932. It is curious that Fetter, writing in 1931, interpreted the political causes of pre-Depression inflation in Chile as the desire to reduce real debts held by landowners, while the typical defense of (potentially inflationary) Keynesian policies now is that it will increase employment of workers.

25 A detailed study of tax policy in Czcchoslovakia is presented by Pryor (1979).

${ }^{26}$ The better performance of the Latin American countries compared to the U.S. extends Choudhuri and Kochin's (1980) argument concerning the beneficial effect of exchange rate devaluations, although we are suggesting that other factors were also important. In particular, Jonung's argument in Brunner (1980) would appear mistakenly to have credited monetary policy, as opposed to exchange rate policy and export mix, as factors determining the relatively better performance of the Swedish economy.

${ }^{27}$ With the fiscal deficit and the trade surplus rising, one might ask why there was any decline in output, and the answer of course is the decline in investments. Data do not permit investigation of savings/consumption shifts. 


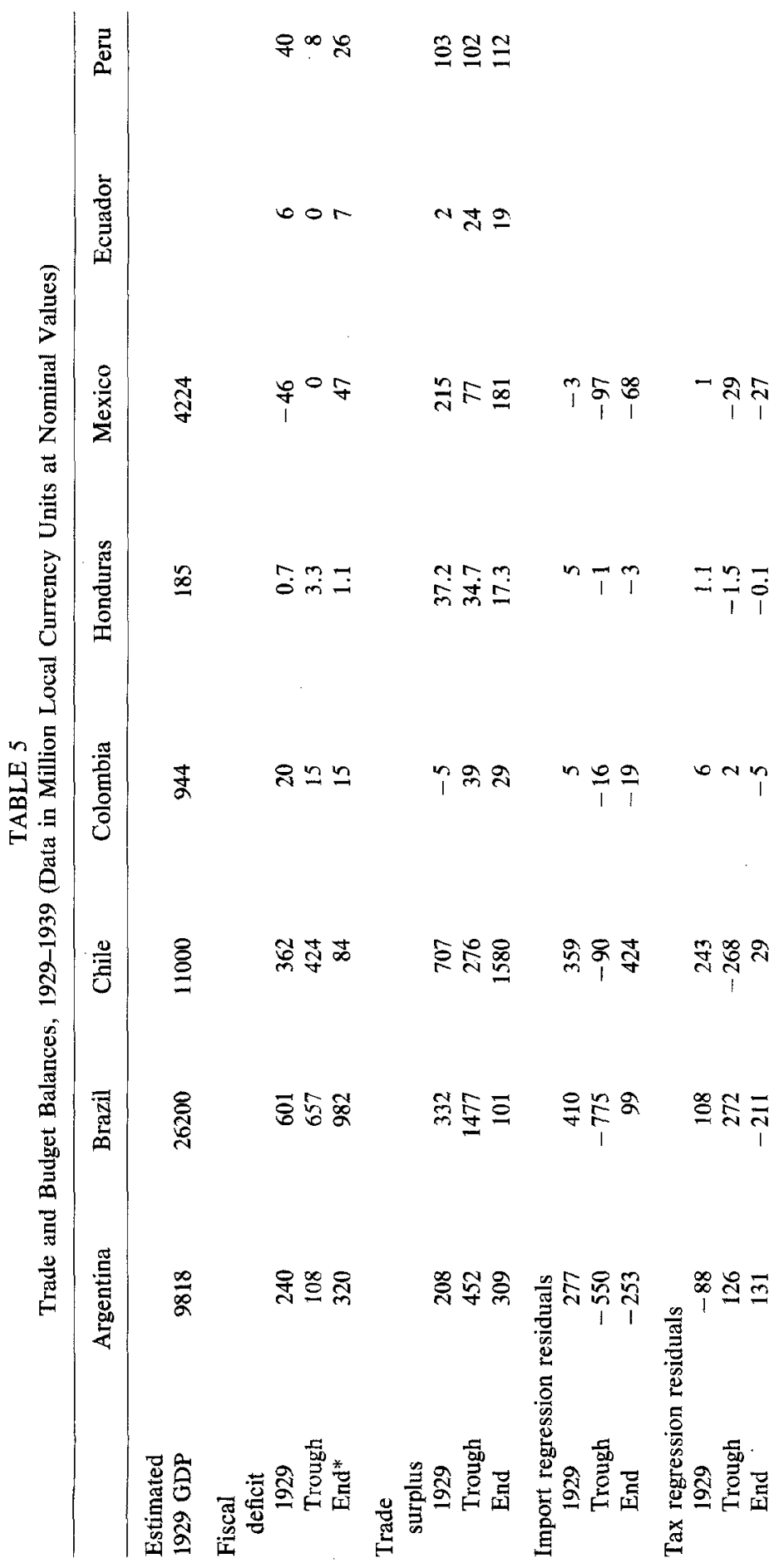




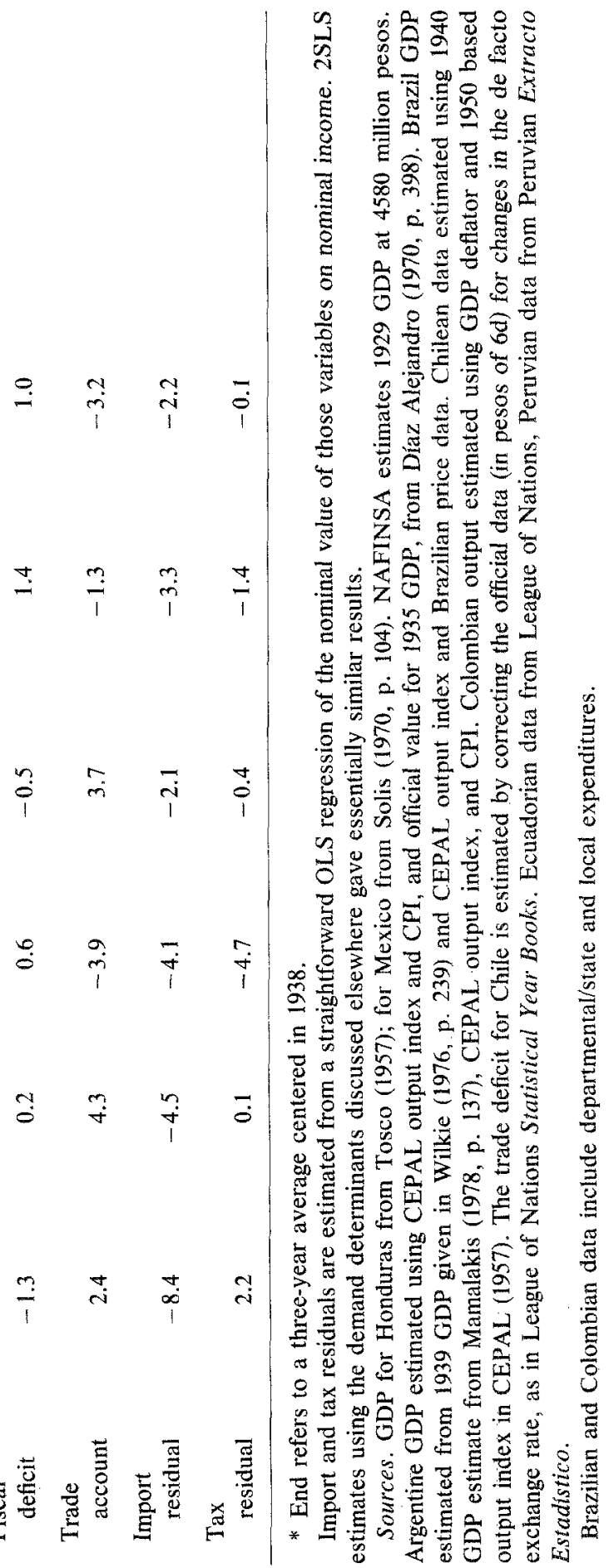



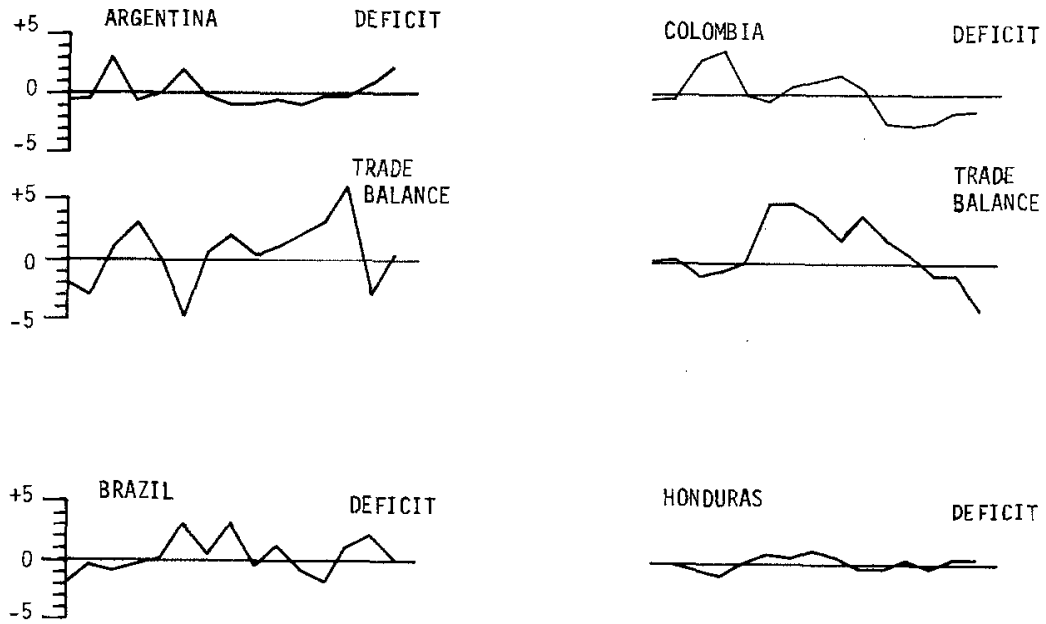

TRADE
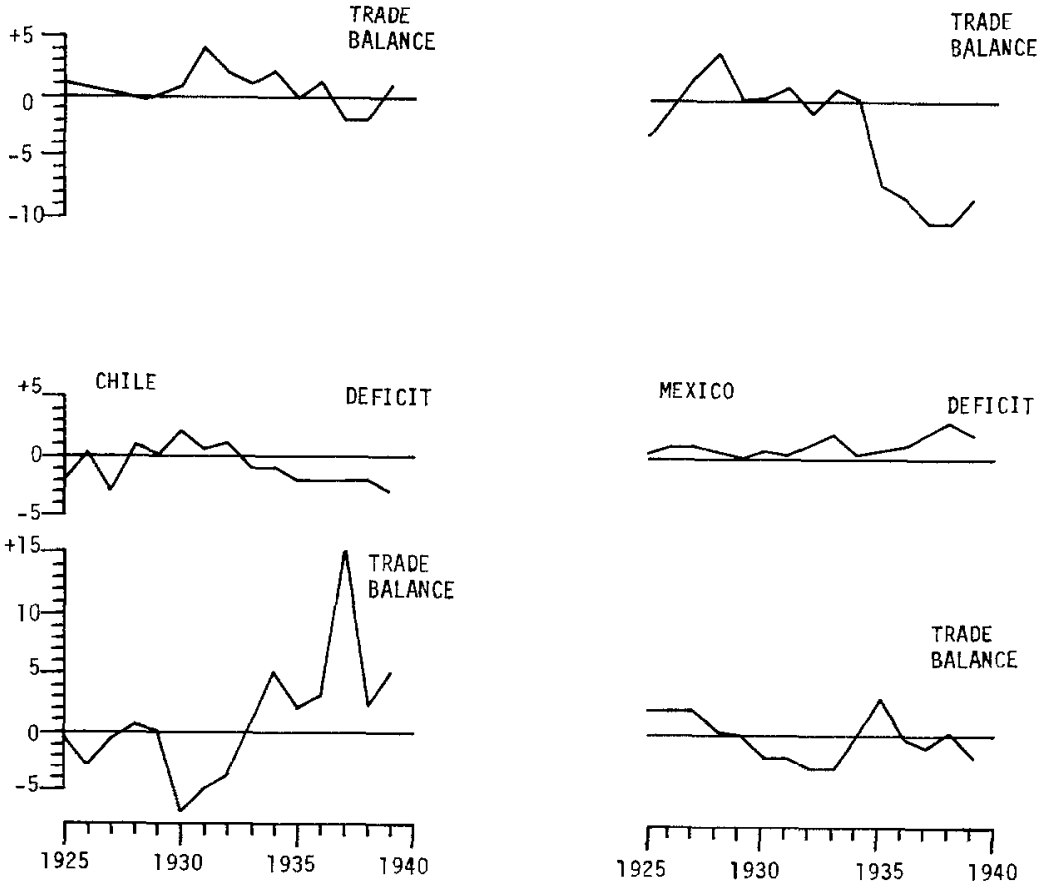

GRAPH 2. Government deficit and trade balance 1925-1939. Differences from 1929 levels as percentage of 1929 GDP. 
to $70 \% .{ }^{28}$ Of course, it is not clear how this profit outflow would be affected by the opposing factors of lowered prices on reduced post-1929 volume, and higher exchange rates together with exchange controls. ${ }^{29}$ The existing balance of payments data are simply too weak to help here. Second, we might note the significant increase in many countries in the production of raw material inputs-especially cement and iron and steelduring the Depression decade. The impact of this process on income via the multiplier has not yet been investigated.

\section{FULL EMPLOYMENT DEFICITS AND GOVERNMENT EXPENDITURES}

Recent studies have argued that the analysis of the effects of government spending should not utilize the actual budget, but rather the full employment budget deficit (or surplus). Different techniques of estimating the latter are presented in the literature; our own estimates ${ }^{30}$ are presented in Table 6. Full employment taxes were estimated by regressing "real" taxes (i.e., nominal taxes divided by the price deflator ${ }^{31}$ utilized in Table 1) on actual real output, and then substituting in the resulting equation an. estimate of full employment output (obtained by projecting the average growth of output over the two decade period onto the 1929 level). The table reports differences between each year and 1929 totals, as a fraction of trend real GDP, and suggests that the Latin American countries did not engage in as significant countercyclical policy as did Australia, the U.S., and the U.K. ${ }^{32}$ The results for Brazil and Colombia still indicate

${ }^{28}$ Sources are CEPAL (1957, Cuadros 10 and 14) for Colombia; Banco Central Economic Review Second Series Vol. 1, (1957, p. 12) for Argentina; Cuadro 9 of Tosco (1957) for Honduras; Cuadro 1 of Olmedo (1942) for Mexico; and Mamalakis and Reynolds (1965, p. 378). Thorp and Bertram (1978) report for Peru individual company returned values of $50 \%$ in copper, and only $10 \%$ in petroleum.

${ }^{29}$ CEPAL (1951, p. 279) estimates that the effective decline in Chile's returned value of exports was only half of the nominal decline.

${ }^{30}$ Brown's (1956) study of the U.S. was updated by Peppers (1973), who estimated the full employment taxes on the basis of estimates of wages, salaries, and profits corresponding to potential GNP, while also accounting for nondiscretionary government expenditures (e.g., unemployment benefits). Middleton's (1981) analysis of the U.K. involved significant recalculation of the actual budget-to eliminate "fiscal window-dressing" - and estimated constant employment expenditures and receipts. These latter result from disaggregating taxes and then using a calculated tax elasticity to adjust for the difference between actual and full employment income, all at nominal prices. Both authors refer the reader to unpublished appendices for details. The disaggregation of taxes is appealing, but impractical for a comparative study, especially because the composition of full employment output (specifically, between traded and nontraded goods) would affect the estimates as much as the assumed levels of income.

${ }^{3 !}$ Exceptions are the U.S. and Canada, for which a deflator for government expenditures exists, and Colombia, for which CEPAL provides real government and tax totals.

${ }^{32}$ The reader is reminded that both Peppers (1973) and Middleton (1981) support the revisionist interpretation downplaying the countercyclical role exercised by fiscal policy in the U.S. and the U.K. during the Depression. 
TABLE 6

Changes in Real Deficits Compared to 1929 Level, as Percentage of Trend GDP

\begin{tabular}{|c|c|c|c|c|c|c|c|}
\hline Country & Deficit & 1930 & 1931 & 1932 & 1933 & 1934 & 1935 \\
\hline \multirow[t]{2}{*}{ Argentina } & Actual & 2 & 0.5 & -0.8 & -0.7 & -0.2 & -0.8 \\
\hline & $\mathrm{FED}^{a}$ & 0.4 & -0.3 & -0.3 & -1.0 & -0.2 & -0.8 \\
\hline \multirow[t]{2}{*}{ Brazil } & Actual & 3.6 & 0.7 & 3.8 & -0.3 & -0.9 & -1.3 \\
\hline & FED & 0.9 & -1.1 & 0.7 & -1.8 & -0.2 & -1.8 \\
\hline \multirow[t]{2}{*}{ Chile } & Actual & 2.6 & 3.4 & 1.7 & -2.1 & -2.6 & -2.5 \\
\hline & FED & 0.4 & -2.9 & -7.0 & -7.8 & -7.6 & -6.2 \\
\hline \multirow[t]{2}{*}{ Colombia } & Actual & -0.2 & 0.5 & 1.2 & 1.9 & 0.5 & -2.5 \\
\hline & FED & 0.8 & 1.1 & 1.7 & 1.6 & -1.7 & -3.3 \\
\hline \multirow[t]{2}{*}{ Mexico } & Actual & 0.8 & 0.3 & 1.0 & 1.7 & 2.2 & 0.8 \\
\hline & FED & -0.4 & -0.7 & -0.5 & 0.2 & 0.6 & 0.7 \\
\hline \multirow[t]{2}{*}{ Australia } & Actual & 2.6 & 1.8 & -0.7 & -0.5 & -1.0 & -1.5 \\
\hline & FED & 1.2 & 2.6 & 2.2 & 2.5 & 2.5 & 1.9 \\
\hline \multirow[t]{2}{*}{ Canada } & Actual & 4.0 & 6.9 & 7.6 & 5.3 & 4.9 & 4.2 \\
\hline & FED & 1.8 & -2.2 & -1.7 & 0.2 & 1.2 & 1.3 \\
\hline \multirow[t]{4}{*}{ U.S. } & Actual & 1.3 & 4.8 & 4.0 & 3.4 & 4.6 & 3.7 \\
\hline & FED & 0.8 & 2.4 & 1.5 & 1.0 & 2.2 & 2.5 \\
\hline & Peppers' & & & & & & \\
\hline & FED & 0.3 & 1.7 & 0.3 & -0.7 & 1.1 & 0.4 \\
\hline \multirow[t]{4}{*}{ U.K. } & Actual & -0.2 & 0.0 & 0.8 & -0.2 & 0.2 & 0.3 \\
\hline & FED & 1.0 & 2.0 & 2.4 & 1.4 & 1.2 & 1.7 \\
\hline & Middleton's & & & & & & \\
\hline & FED & -0.7 & -2.1 & -2.6 & -3.8 & -2.8 & -1.6 \\
\hline
\end{tabular}

$" \mathrm{FED}=$ full employment deficit, i.e., expenditures minus taxes, estimated by the procedure described in the text.

Source. Author's calculations, as described in text, Peppers (1973, p. 302), and Middleton (1981, p. 280). Note that Middleton recalculated the actual budget, which may account for a significant part of the difference between his estimates and those presented here.

countercyclical actions, although the latter's positive response disappears if the less reliable departmental and local government expenditure totals are ignored, and attention is focused solely on the national government.

Our estimates are undoubtedly very crude, as indicated by the comparison in Table 6 of the two published studies, and open to considerable refinement. ${ }^{33}$ Rather than engage in such an exercise, some other comments

${ }^{33}$ There are three problems with our procedure. First, a very simple tax function is assumed. Second, there are problems with price deflators. Colombia's data probably overestimates the post-1929 fall in prices, and hence the subsequent rise in real government expenditures, while the opposite may be true, for example, in Chile. Third, this method reduces to comparing the growth in real government expenditures (as a percentage of total output) with the product of the marginal tax rate times the assumed growth of trend GDP. Estimates of the marginal tax rate resulted in the surprisingly large variation of from 0.045 in Mexico to 0.365 in Australia. 
are appropriate. We might note that there was a tendency for greater deficits in the more federated countries-Colombia, Brazil, Australia and the U.S. As noted above, the implicit attribution of meritorious intent to makers of countercyclical policy may well be erroneous, as increased government outlays often went to help people in the upper ends of the income scale, (such as coffee, beef, and wheat farmers in Brazil and Argentina), or resulted from armed conflict, such as the Chaco War, the border clashes between Peru and Colombia, and internal strife in Brazil, Central America, and elsewhere. Finally, the full employment budget may not be the most appropriate concept for comparing countries. Regardless of whom the increased government expenditures were supposed to help, the budget decisions were made in the context of falling prices and tax revenues, especially because of import and export taxes. Given the prevailing orthodoxy, a realistic counterfactual must consider the pressure for a balanced budget. This assertion is supported by regressing the growth of government expenditures (GOVERNMEN $\Gamma$ ) on expected deficits (DEFICIT) and the difference between expected output and full employment output (GAP), all deflated by income, and approximating the latter two by their actual values lagged one year. For a pooled sample for all countries in Table 6 for those post-1929 years when output was less than its 1929 level, we obtain GOVERNMENT $=-0.30$ DEFICIT $+0.03 \mathrm{GAP}+$ DUMMIES; $R^{2}=0.41$, with $t$ coefficients of 3.72 and 1.70 , respectively. The coefficient on the DEFICIT is statistically significant at the $5 \%$ level, but obtaining positive coefficients on the dummy variables for Brazil, Colombia, the U.S., Canada, and Australia does not allow us to revise the negative judgment on countercyclical policy in countries like Chile.

\section{EXPORT PERFORMANCE}

The nominal domestic currency value of exports dropped after 1929 in all Latin American countries. By the end of the period, the nominal value had exceeded that of 1929 in just half of our countries. ${ }^{34} \mathrm{We}$ shall separate our analysis of export value into its two components, quantity and prices, as each has a separate story to tell.

From the pre-Depression peak to the trough, the export quantum in Table 7 declined in all countries except Brazil. ${ }^{35}$ By the end of the period the export quantum was greater than the pre-Depression level in seven countries. ${ }^{36}$ It is noteworthy that in all of these countries oil and/or coffee

\footnotetext{
${ }^{34}$ Only in Honduras did the nominal value fall between 1932 and the end of the decade, because of the decline of exports due to disease. See Bulmer-Thomas (1982).

${ }^{35}$ For a more detailed discussion of price and quantity trends for these countries, see Twomey (1982a).

${ }^{36}$ Note the lack of correlation between growth of export quantum and growth of GDP. In three of the six countries for which the comparison is possible, the two variables moved in different directions between 1929 and 1938.
} 
TABLE 7

Index Numbers for Exports and Prices (1929 = 100)

\begin{tabular}{|c|c|c|c|c|c|c|c|}
\hline \multirow[b]{2}{*}{$\begin{array}{c}\text { Country } / \\
\text { ycar }\end{array}$} & \multicolumn{3}{|c|}{ Exports } & \multirow[b]{2}{*}{$\begin{array}{c}\text { Exchange } \\
\text { rate to } \\
\text { U.S.\$ }\end{array}$} & \multirow[b]{2}{*}{ CPI } & \multirow[b]{2}{*}{$\begin{array}{l}\text { Terms } \\
\text { of } \\
\text { trade }\end{array}$} & \multirow{2}{*}{$\begin{array}{c}\text { Weighted } \\
\text { index of } \\
\text { world } \\
\text { cxports }\end{array}$} \\
\hline & $\begin{array}{c}\text { Domestic } \\
\text { currency } \\
\text { value }\end{array}$ & Quantity & $\begin{array}{l}\text { Domestic } \\
\text { price }\end{array}$ & & & & \\
\hline \multicolumn{8}{|l|}{ Argentina } \\
\hline 1932 & 59 & 87 & 72 & 165 & 93 & 75 & - \\
\hline 1938 & 65 & 62 & 103 & 130 & 92 & 112 & 97 \\
\hline \multicolumn{8}{|l|}{ Bolivia } \\
\hline 1932 & 37 & 59 & 78 & 172 & NA & NA & - \\
\hline 1938 & 72 & 80 & 92 & 1080 & $\mathrm{NA}$ & NA & NA \\
\hline \multicolumn{8}{|l|}{ Brazil } \\
\hline 1931 & 88 & 116 & 72 & 171 & 88 & 53 & - \\
\hline 1939 & 145 & 158 & 87 & 230 & 131 & 45 & 123 \\
\hline \multicolumn{8}{|l|}{ Chile } \\
\hline 1932 & 49 & 29 & 120 & 406 & 104 & 55 & - \\
\hline 1938 & 150 & 89 & 161 & 300 & 168 & 51 & 82 \\
\hline \multicolumn{8}{|l|}{ Colombia } \\
\hline 1931 & 71 & 96 & 81 & 100 & 69 & 83 & - \\
\hline 1938 & 133 & 132 & 101 & 177 & 112 & 60 & 131 \\
\hline \multicolumn{8}{|c|}{ Costa Rica } \\
\hline 1932 & 52 & $89^{*}$ & $59 *$ & 110 & NA & NA & 一 \\
\hline 1938 & 77 & $114^{*}$ & $64^{*}$ & 143 & NA & NA & 120 \\
\hline \multicolumn{8}{|l|}{ Ecuador } \\
\hline 1932 & 56 & 80 & 76 & 112 & 63 & 82 & - \\
\hline 1937 & 190 & 113 & 177 & 284 & 179 & 63 & 131 \\
\hline \multicolumn{8}{|c|}{ El Salvador } \\
\hline 1932 & 37 & 77 & 60 & 124 & NA & 49 & - \\
\hline 1938 & 74 & 103 & 71 & 124 & NA & 51 & 126 \\
\hline \multicolumn{8}{|c|}{ Guatemala } \\
\hline 1932 & 42 & $80^{*}$ & $56^{*}$ & 100 & NA & NA & - \\
\hline 1937 & 65 & $91^{*}$ & $73^{*}$ & 100 & NA & NA & NA \\
\hline \multicolumn{8}{|l|}{ Honduras } \\
\hline 1932 & 74 & $82^{*}$ & $92^{*}$ & 100 & 91 & NA & - \\
\hline 1936 & 51 & $48^{*}$ & $103^{*}$ & 100 & 93 & NA & 103 \\
\hline \multicolumn{8}{|l|}{ Mexico } \\
\hline 1932 & 51 & 58 & 93 & 151 & 79 & 60 & - \\
\hline 1938 & 142 & 50 & 192 & 218 & 119 & 132 & 110 \\
\hline \multicolumn{8}{|l|}{ Nicaragua } \\
\hline 1932 & 42 & $59^{*}$ & $61^{*}$ & 100 & NA & NA & - \\
\hline 1938 & $55 \mathrm{G}$ & $88^{*}$ & $42 \mathrm{G}^{*}$ & 490 & NA & NA & 114 \\
\hline \multicolumn{8}{|l|}{ Paraguay } \\
\hline 1932 & 95 & $84^{*}$ & $83^{*}$ & 115 & NA & NA & - \\
\hline 1938 & $90 \mathrm{G}$ & $67^{*}$ & $76 G^{*}$ & 235 & NA & NA & NA \\
\hline \multicolumn{8}{|l|}{ Peru } \\
\hline 1932 & 53 & 85 & 68 & 190 & 86 & 63 & - \\
\hline 1938 & 102 & 105 & 97 & 180 & 98 & 66 & 119 \\
\hline
\end{tabular}


TABLE 7-Continued

\begin{tabular}{|c|c|c|c|c|c|c|c|}
\hline \multirow[b]{2}{*}{$\begin{array}{l}\text { Country/ } \\
\text { year }\end{array}$} & \multicolumn{3}{|c|}{ Exports } & \multirow[b]{2}{*}{$\begin{array}{c}\text { Exchange } \\
\text { rate to } \\
\text { U.S.\$ }\end{array}$} & \multirow[b]{2}{*}{ CPI } & \multirow[b]{2}{*}{$\begin{array}{c}\text { Terms } \\
\text { of } \\
\text { trade }\end{array}$} & \multirow{2}{*}{$\begin{array}{c}\text { Weighted } \\
\text { index of } \\
\text { world } \\
\text { exports }\end{array}$} \\
\hline & $\begin{array}{c}\text { Domestic } \\
\text { currency } \\
\text { value }\end{array}$ & Quantity & $\begin{array}{c}\text { Domestic } \\
\text { Price }\end{array}$ & & & & \\
\hline \multicolumn{8}{|l|}{ Uruguay } \\
\hline 1932 & 62 & $65^{*}$ & $81^{*}$ & 210 & 99 & NA & - \\
\hline 1938 & 103 & $81^{*}$ & $120^{*}$ & 178 & 98 & NA & 105 \\
\hline \multicolumn{8}{|l|}{ Venezuela } \\
\hline 1932 & 81 & 85 & 96 & 127 & 84 & 89 & - \\
\hline 1937 & 109 & 128 & 81 & 67 & 76 & 45 & 148 \\
\hline
\end{tabular}

"NA" signifies not available.

The "Weighted index of world exports" was generated using the individual country weights of the separate products and world total exports, from International Yearbook of Agricultural Statistics, I amartine Yates (1959)-giving data for 1937-and Metallgesellschaft. (1938).

Sources. Value data is from League of Nations International Trade Statistics 1930, 1933, 1938. Quantity and terms of trade series from Wilkie (1980), reporting CEPAL data. An * indicates data are based on author's calculations, using ITS data, including those products which accounted for more than $5 \%$ of trade value in 1929. This method yielded estimates very close to the CEPAL estimates for the other countries. Export price indices are author's calculations. Exchange rates from Wilkie (1974).

Consumer price indices (CPI) from series in tables above, and from Ecuador (1944). Venezuelan price index is WPI. For export values, a " $\mathrm{G}$ " indicates sources's data apparently are values in terms of old gold prices.

were important in pre-Depression trade, suggesting that it was the peculiarity of those products' supply process which led to this result. Both have a lengthy and costly lead-in time, locking producers into long-run production strategies. Of course, a major difference between them was the changing world demand, with world output of petroleum growing some $40 \%$ during 1929-1938, more than that of any other major primary product. Although the general level of world trade during the $1930 \mathrm{~s}$ was lower than that of the late $1920 \mathrm{~s}$, there are other examples of products with an upwards volume trend, although none of them was so important as to change the direction of any other country's overall export quantum. Note that pre-Depression diversity of exports was no guarantee of an ability to weather the storm of declining demand, as can be seen by contrasting Ecuador and Peru with Mexico and Paraguay.

Domestic prices of exports are determined by two factors, the "world price" and the exchange rate. Over the period 1929-1938, few products improved relative to the overall price level in the U.S. or U.K.; in a way, this is the well-known CEPAL declining terms of trade argument. 
It should also bc notcd that the world prices of the majority of Latin American export products dropped between 1925 and 1929; virtually all of them more than the average price levels in the U.S. or U.K.

Turning to exchange rates, we note in Table 7 that the general practice in Latin America was suspension of convertibility and/or devaluation sooner than the U.S., U.K., or Germany, and continued devaluations after those countries devalued during 1931-1933. The reduction of export earnings and the drying up of foreign loans before the crash on Wall Street caused great balance of payments pressure in Latin America, and, in spite of the growth of central banks in the region during this period, countries were not reluctant to break the gold standard rules by devaluations. Colombia and three of the five Central American countries had not devalued by their trough year; Colombia waited until 1932 due to its having accumulated substantial amounts of gold during the 1920s because of foreign lending and the Panama settlement, while the other countries followed the U.S. dollar.

It is interesting to note that five countries effectively let their exchange rate revalue between the trough and the end of the period. It is tempting to speculate that this was due to the strengthening of the world demand for those country's exports-minerals and temperate climate food products-in contrast to the other Latin American countries, which can be classified into two groups: producers of coffee and other beverages (cocoa and mate), which suffered from oversupply, or those Central American countries which pegged their currencies to the U.S. dollar. There are two exceptions to this generalization. Bolivia had suffered tremendous inflation because of the Chaco war. ${ }^{37}$ Mexico, on the other hand, provides a strong contrast with Peru, Uruguay, and Argentina, and one is led to search for the explanation of its short-term export difficulties in the structural transformations still occurring there as a result of the Revolution.

This discussion of export performance has emphasized commodity specific characteristics rather than internal price changes. This reflects our observation that a country's experience with exchange rate devaluations and domestic inflation generally had less impact on the volume of its exports than did the product mix of exports, or what Diaz Alejandro calls their "luck in the commodity lottery" $(1981$, p. 4). One attempt at quantifying this hypothesis is to use the values in Table 7 to correlate export quantum with either the "real price" of exports (unit domestic price divided by CPI) or the weighted index of world exports. The latter is calculated for 1937/1938 (and also presented in Table 7) for each country by summing by commodity the product of an index of world

\footnotetext{
${ }^{37}$ Bolivia's need to devalue may also be due to her exports not having recovered as well as those of other countries, because her tin mines were more difficult to reopen after they had shut down. See CEPAL (1958a, pp. 30-31).
} 
exports and the percentage of that country's total exports (in 1929) accounted for by that commodity. The price variable is in fact strongly negatively correlated $(-0.78)$ to the export quantum, in contrast to what one would expect in a supply curve relationship. The weighted world exports is positively correlated $(0.66)$. We conclude that movements along the export supply curve caused by devaluations and other measures affecting internal prices were not as significant as shifts of supply curves due to cartel formation, together with price support programs for certain products under empire preference schemes. Generally, these other factors were commodity specific.

\section{MONETARY FACTORS}

The money supply does not perform well as the sole determinant of aggregate demand, as was pointed out above. The explanation for this is straightforward; as a result of the transference to Latin America of the economic and financial problems of North America and Europe, there was widespread suspension of gold shipments, defaulting on the foreign debt, and exchange rate devaluations. The abandonment of the gold standard tended to sever the link running from money (especially gold) to income. . $^{38}$

To analyze this process, we have adopted the Friedman-Schwartz (1963) technique of focusing on the monetary base $\mathrm{e}^{39}$ and comparing changes in it with changes in the money supply, for six Latin American countries. It is curious to note in Table 8 that the two countries which did not have a central bank in 1929, Brazil and Uruguay, had the highest ratios of gold to high powered money. In any event, there are three factors to be noticed in Table 8 . First, the average ratio between high powered money and gold was much higher that the marginal ratio, so that, for example, a given percentage reduction in gold did not lead to a corresponding decrease in the monetary base or the total money supply. Second, there is a strong reduction in this "offset coefficient" after the imposition of exchange controls; this indicates the severance of the traditional link in

${ }^{38}$ Recall the frequency in Table 1 of large changes in velocity in the early $1930 \mathrm{~s}$.

${ }^{39}$ The monetary base, or high powered money, is calculated as the sum of currency in the hands of the public and the reserves of the commercial banks. This calculation, based on data from the League of Nations Commercial Banks in 1931, 1934, 1936, and 1938, as well as various issues of the Statistical Year Book, is not able to include gold coin in the hands of the public, the extent of which is unknown at least to the author. The League of Nations presents statistics generated on a presumably uniform basis (the data on Chile does undergo revisions with regard to bank reserves); although it would be preferable to use national sources it is not clear that the various Memoria of the Central Banks themselves present sufficiently detailed information. Our analysis was not possible for two countries: Mexico's financial system underwent great changes during the early thirties for a number of reasons (see Cardenas, 1982), while none of the League of Nations sources provides any banking data for Honduras. 
TABLE 8

Money Supply Process

\begin{tabular}{|c|c|c|c|c|c|c|}
\hline & Brazil & Chile & Colombia & Ecuador & Peru & Uruguay \\
\hline \multicolumn{7}{|l|}{1929 Ratio of } \\
\hline HPM \& Gold & 2.28 & 0.98 & 1.38 & 0.97 & 0.85 & 2.13 \\
\hline M1 \& HPM & 1.64 & 1.77 & 1.77 & 1.47 & 1.83 & 0.96 \\
\hline M1 \& Gold & 3.75 & 1.73 & 1.38 & 1.43 & 1.56 & 2.04 \\
\hline \multicolumn{7}{|c|}{ Regression coefficients } \\
\hline HPM \& Gold & 0.41 & 0.06 & 0.64 & 0.30 & 0.36 & 0.98 \\
\hline M1 \& HPM & 2.33 & 1.42 & 1.40 & 1.16 & 1.07 & 0.53 \\
\hline M1 \& Gold & 1.29 & 0.11 & 1.18 & 0.47 & 0.79 & 0.54 \\
\hline \multicolumn{7}{|c|}{$\begin{array}{l}\text { Preexchange control period } \\
\text { regression coefficient }\end{array}$} \\
\hline HPM \& Gold & 0.63 & 0.95 & 0.69 & 0.63 & & 1.21 \\
\hline M1 \& HPM & 1.50 & 1.02 & 1.49 & 1.43 & & 0.55 \\
\hline \multicolumn{7}{|c|}{$\begin{array}{l}\text { Exchange control period } \\
\text { regression coefficient }\end{array}$} \\
\hline HPM \& Gold & 0.07 & -0.31 & 0.49 & 0.16 & & 0.05 \\
\hline M1 \& HPM & 2.75 & 1.51 & 1.31 & 1.11 & & 0.20 \\
\hline
\end{tabular}

Notes. Gold includes gold and foreign exchange. HPM is high powered money.

Preexchange control period are the years before the imposition of exchange controls, as indicated in League of Nations Statistical Year Book 1941. Peru is not listed as having utilized official exchange controls.

Sources. Data from League of Nations Commercial Banks, and Statistical Year Book, various years. Brazilian data from Neuhaus (1975).

Regression coefficient reports the estimated coefficient of an equation using first differences of the two variables, with the second variable the independent variable.

the price specie flow mechanism. Finally, although the marginal ratio of the money supply to high powered money is also smaller than the average in 1929, breaking down that regression into periods does not produce consistent results. ${ }^{40}$

Many central banks were created in the area during the interwar period. It is ironic that the two countries which provided technical assistance in that process, while serving as "role models" - the U.K. and the U.S.were the ones whose abandonment of the gold standard in the early $1930 \mathrm{~s}$ is often interpreted as being one of the most serious of the proximate

\footnotetext{
${ }^{40}$ Research on Canada and Australia has suggested that banks considerably altered their "excess reserves" depending on the perceived demand for justifiable and prudent loans; see Courchene (1969) and Schedvin (1970). The implication is that these demand factors had a significant impact on the quantity of money. Pursuit of this hypothesis would necessitate more complete data series, but some of this analysis is presented in detail for Brazil by Neuhaus (1975, pp. 114-125).
} 
factors determing the world-wide depth of the Depression..$^{41}$ Most of the countries analyzed lost nearly all of their gold stocks, and few had replenished them (in even nominal terms) by $1936 .{ }^{42}$ That the money supply increased in spite of the drop of gold and foreign exchange reserves is attributable to deficit spending and greater leniency in terms of bank reserves, the clearest examples of which are Chile, Brazil, and Bolivia.

\section{CONCLUDING OBSERVATIONS}

A recurrent theme in many sections above has been the atypical experience of the United States: flatter supply curve, larger drop in aggregate demand, stronger decline in investments compared to exports, and the uniqueness of the widespread bank failures. The strong implication is the inappropriateness of comparisons which use the U.S. as a standard. The overall Latin American experience appears not dissimilar from the broad spectrum provided by Europe. We have argued that Brazil is the only country in the region to engage in significant countercyclical fiscal policies, while noting that policies adopted to cushion the export decline had significant expansionary effects, a relationship which was probably not well appreciated at the time.

An exploratory essay such as this inevitably raises many questions and points to areas in need of further research. For example, the monetary histories of the region have not been written. ${ }^{43}$ In spite of the jockeying for influence represented by the Kemmerer and Niemeyer missions, it would appear that the central banks each established did not differ much in design, and, moreover, that the pre-1929 existence of a central bank was not an important factor determining a country's reaction to and performance during the Depression. With regard to export performance, one would ask why there was such a different response in the different primary products, the answer to which calls for investigation of storage policies, as well as why some cartels were more successful than others.

Finally, our analysis of aggregate demand attempts to trace a middle path between the LDC perspective concentrating on the decline in exports, and the simpler version of Keynesian analyses oriented solely towards investments. One wonders if during the 1920 s some of the Latin American countries were evolving toward demand growth generated internally from investments, instead of exports, while maintaining essentially free trade.

${ }^{41}$ These financial aspects are thoroughly discussed by Kindleberger (1973), whose analysis focusing on the lack of financial leadership on the part of the U.S. and the U.K. expands ideas earlier formulated by Brown (1940).

${ }^{42}$ Following the practice of many governments of that time, the large effective devaluations of these currencies are not reflected in Table 8 in the gold totals by 1935; in most cases the eventual devaluation "profits" accrued to the government which used them to finance deficits.

${ }^{43}$ But see Triffin (1944). 
This question gains relevance when we notice that some of these same countries are now moving towards dismantling the external control regimes which are an important legacy of the 1930s.

\section{APPENDIX}

Sources. For the following countries, the major sources for data: European countries, Mitchcll (1975); Canada, Urquhardt and Buckley, (1965); USA, US Dept. of Commerce (1975); Japan, Okhawa and Shinohara (1978); Australia, Butlin (1962). Indian data from Singh (1965) and unpublished output estimates of Heston. Turkish output data from Hale (1981, Tables 3.2, 4.5); prices and money from League of Nations Statistical Year Book.

Except where noted in the text, the Latin American data on real output, industrial production, and construction are from CEPAL (1978). The League of Nation's yearbooks and United Nations (1949) provide the major source for wage, price, and monetary data. Additional sources are the following. For Argentina, money supply from Halperin (1968), wages from Di Tella and Zymelman (1973), trade and government totals from Chu (1972); for Brazil, monetary data from Neuhaus (1975), prices, trade and government from the Anuario Estatístico. Chile: wages from Estadistica Chilena, industrial and total output from Ballesteros and Davis (1963), using their cited CEPAL data after 1925, and their own index 1920-1925. This follows Mamalakis (1978), although it is interesting to note that CEPAL (1978) does not include their own pre-1940 estimates for Chile. Government totals supplemented with data from League of Nations (1938) and Chile (1933). Colombia: money, exports, and government from Chu (1972), wages from Urrutia and Arrubla (1970), CPI from Wilkie (1974), GDP deflator from CEPAL (1957). The Mexican price, output, construction, and money data are from Solis (1970), trade and government data from Anuario Estadistico. Honduras is taken from Tosco (1952) and (1957). Output estimates for Uruguay presented by Millot (1972) are not utilized here, less because of their reference to 1930 than because of the unexplained change in the ratio of services to total output between their estimates for 1930 and official data for 1935 and later years.

For the Latin American countries, the nominal GDP estimate only exists for Mexico and Honduras; for the other countries these were generated by multiplying the price series and the CEPAL (1978) output series. This procedure was also followed for Czechoslovakia, France, and Yugoslavia.

Price data were CPI except for the following: WPI for Germany, Greece, Austria, Italy, Spain, and Sweden; GDP deflator for Hungary and Mexico. Criteria for selection was goodness of fit in the supply equation, the author's judgment on economy wide coverage of products, and, inevitably, 
length of available time series. The monetary aggregate was M1, except for Czechoslovakia, Sweden, and Spain, for which it was M2.

\section{REFERENCES}

Ballesteros, M. A., and Davis, T. E. (1963), "The Growth of Output and Employment in the Basic Sectors of The Chilean Economy, 1908-1957." Economic Development and Cultural Change 11, 152-76.

Brown, E. C. (1956), "Fiscal Policy in the "Thirties: A Reappraisal." American Economic Review 46, 857-79.

Brown, W. A. (1940), The International Gold Standard Reinterpreted 1914-1934. New York: National Bureau of Economic Research.

Brunner, K. (Ed.) (1980), The Great Depression Revisited. The Hague: Martinus Nijhoff. Bulmer-Thomas, V. (1982), "The Central American Economies in the Inter-War Period," to appear in R. Thorp, Ed.

Butlin, N. G. (1962), Australian Domestic Product, Investment and Foreign Borrowing, 1861-1939. Cambridge: Cambridge Univ. Press.

Cardenas, E. (1982), "Economic Policy during the Great Depression," to appear in R. Thorp, Ed.

CEPAL (ECLA) (1951), Economic Survey of Latin America 1949, New York.

CEPAL (ECLA) (1957), Analyses and Projections of Economic Development, Vol. 3, "The Economic Development of Colombia Anexo Estadistico." As published by Dane (SM/ CE 70/1), which is presumably identical to CEPAL's E/CN.12/365/Add.1/Rev. 1.

CEPAL (1958a), Analisis y Proyecciones del Desarrollo Economico, IV, "El Desarrollo Economico de Bolivia." Mexico: E/CN.12/430 y Add.1/Rev. 1.

CEPAL (1958b), El Desarrollo Economico de la Argentina Anexo. Santiago: E/CN.12/429/ Add.4.

CEPAL (1978), Series Historicas del Crecimiento de America Latina. Santiago de Chile.

Chile (1933), Sinopsis Geografica Estadistica de la Republica de Chile. Santiago.

Choudhuri, E. U., and Kochin, L. A. (1980), "The Exchange Rate and the International Transmission of Business Cycle Disturbances: Some Evidence from the Great Depression." Journal of Money, Credit, and Banking 12, 565-74.

Chu, D. S. C. (1972), "The Great Depression and Industrialization in Latin America." Unpublished doctoral dissertation, Yale University.

Courchene, T. J. (1969), "An Analysis of the Canadian Money Supply: 1925-1934." Journal of Political Economy 77, 363-91.

Di Tella, G., and Zymelman, M. (1973), Los Ciclos Economicos Argentinos. Buenos Aires: Paìdos.

Diaz Alejandro, C. F. (1970), Essays on the Economic History of the Argentine Republic. New Haven: Yale Univ. Press.

Diaz Alejandro, C. F. (1981), "Stories of the 1930's for the 1980's." Yale University Economic Growth Center Discussion Paper 376.

Ecuador (1944), Ecuador en Cifras 1938 a 1942. Quito(?) Direccion Nacional de Estadistica.

Fetter, F. (1931), "Monetary Inflation in Chile." Princeton University International Finance Section Study \#3.

Fishlow, A. (1972), "Origins and Consequences of Import Substitution in Brazil." In L. di Marco (Ed.), International Economics and Development. New York: Academic Press.

Fitzgerald, E. V. K. (1981), "Restructuring in a Crisis: The Mexican Economy and the Great Depression," to appear in R. Thorp, Ed.

Fitzgerald, E. V. K. (1982), "ECLA and the Great Depression: A Re-Statement and a Critique." Unpublished manuscript. 
Fleisig, H. W. (1975), Long Term Capital Flows and the Great Depression: The Role of the United States. New York: Arno Press.

Friedman, M., and Schwartz, A. J. (1963), A Monetary History of the United States 18671960. Princeton: Princeton Univ. Press.

Furtado, C. (1963), The Economic Growth of Brazil. Univ. of California Press.

Gandolfi, A. E., and Lothian, J. R. (1977), Review of "Did Monetary Forces Cause the Great Depression?' In Journal of Money, Credit and Banking 19, 679-91.

Gordon, R. J., and Wilcox, J. A. (1980), "Monetarist Interpretations: An Evaluation and Critique." In K. Brunner (Ed.), The Great Depression Revisited. The Hague: Martinus Nijhoff.

Hale, W. (1981), The Political and Economic Development of Modern Turkey. New York: St. Martin's Press.

Halperin, R. A. (1968), "The Behavior of the Argentine Monetary Sector An Econometric Analysis." Unpublished Ph.D. dissertation, Columbia University.

Kindleberger, C. P. (1973), The World in Depression 1929-1939. Univ. of California Press.

Lamartine Yates, P. (1959), Forty Years of Foreign Trade. London: Allen \& Unwin.

Latham, A. J. H. (1981), The Depression and the Developing World 1914-1939. Totowa: Barnes \& Noble.

League of Nations Economic Intelligence Service (1938), Public Finance 1928-1937. Geneva.

Mamalakis, M. (1978), Historical Statistics of Chile. Westport: Greenwood Press.

Mamalakis, M., and Reynolds, C. W. (1965), Essays on the Chilean Economy. Homewood, Ill.: Richard D. Irwin.

Metallgesellschaft (1939), Metal Statistics 1929-1938. Frankfort: Metallgesellschaft Akt.

Middleton, R. (1981), "The Constant Employment Budget Balance and British Budgetary Policy, 1929-1939." Economic History Review 34, 266-86.

Millot, J., et al. (1972), El Desarrollo Industrial del Uruguay. Uruguay: Universidad de la Republica.

Mitchell, B. R. (1975), European Historical Statistics, 1750-1970. New York: Columbia Univ. Press.

Nacional Financiera, S. A. (NAFINSA) (1978), La Economia Mexicana en Cifras. Mexico, D.F.

Neuhaus, P. (1975), Historia Monetaria do Brasil 1900-1945. Rio: IMBEC.

Ohkawa, K., and Shinohara, M. (1979), Patterns of Japanese Economic Development. New Haven: Yale Univ. Press.

Olmedo, A. L. (1942), "Algunos Aspectos de la Balanza Mexicana de Pagos." El Trimestre Economico 9, 14-51.

Pelaez, C. M. (1979), Historia Economica do Brasil. Sao Paulo: Editora Atlas.

Peppers, L. C. (1973), "Full-Employment Surplus Analysis and Structural Change: The 1930's." Explorations in Economic History 10, 197-210.

Pryor, Z. P. (1979), "Czechoslovak Fiscal Policies in the Great Depression." Economic History Review Second Series 32, 228-40.

Schedvin, C. B. (1970), Australia and the Great Depression. Sydney: University Press.

Singh, V. B. (1965), The Economic History of India, 1857-1956. Bombay: Allied Publ.

Solis, L. (1970), La Realidad Economica Mexicana: Retrovision y Perspectivas. Mexico: Siglo Veintiuno.

Stoneman, W. E. (1979), A History of the Economic Analysis of the Great Depression in America. New York: Garland.

Temin, P. (1976), Did Monetary Forces Cause the Great Depression? New York: Norton.

Thorp, R. (Ed.), Latin America in the Great Depression, forthcoming.

Thorp, R., and Bertram, G. (1978), Peru 1890-1977: Growth and Policy in an Open Economy. London: Macmillan.

Tosco, M. (1952), Indice de Precios al Por Menor Para Familias de Ingresos Moderados en Tegucigalpa D.C. Tegucigalpa: Banco Central de Honduras. 
Tosco, M. (1957), Cuentas Nacionales 1925-1955. Tegucigalpa: Banco Central de Honduras. Trescott, P. B. (1982), "Federal Reserve Policy in the Great Contraction: A Counterfactual Assessment." Explorations in Economic History 19, 211-220.

Triffin, R., (1944), "Central Banking and Monetary Management in Latin America." In S. E. Harris (Ed.), Economic Problems of Latin America. New York: McGraw-Hill. Twomey, M. J. (1982a), "Aggregate Supply and Demand in Latin America During the Great Depression." Manuscript.

Twomey, M. J. (1982b), "Economic Fluctuations in Argentina, Australia and Canada during the Great Depression." Manuscript.

United Nations (1949), Statistical Yearbook. Lake Success, New York.

U.S. Department of Commerce (1975), Historical Statistics of the United States from Colonial Times to 1970. Washington, D.C.: GPO.

Urquhart, M. C., and Buckley, K. A. H. (1965), Historical Statistics of Canada. Cambridge: Cambridge Univ. Press.

Urrutia, M. and Arrubla, M. (1970), Compendio de Estadisticas Historicas de Colombia. Bogota: Universidad Nacional.

Van der Wee, H. (1972), The Great Depression Revisited. The Hague: Martinus Nijhoff.

Wilkie, J. W. (and others) (various years), Statistical Abstract of Latin America. Los Angeles: Univ. of California Press.

Wilkie, J. W. (1974), "Statistics and National Policy," Supplement No. 3 to Statistical Abstract of Latin America. Los Angeles: Univ. of California Press.

Zevin, R. B. (1982), "The Economics of Normalcy." Journal of Economic History 42, $43-52$.

Zimmerman, L. J. (1962), "The Distribution of World Income 1860-1960." In E. de Vries (Ed:), Essays in Unbalanced Growth. 's-Gravehage: Mouton. 